2016-09-22

\title{
Unexpected removal of the most neutral cationic pharmaceutical in river waters
}

Fitzsimons, Mark

http://hdl.handle.net/10026.1/8241

10.1007/s10311-016-0582-2

Environmental Chemistry Letters

Springer Science and Business Media LLC

All content in PEARL is protected by copyright law. Author manuscripts are made available in accordance with publisher policies. Please cite only the published version using the details provided on the item record or document. In the absence of an open licence (e.g. Creative Commons), permissions for further reuse of content should be sought from the publisher or author. 
Post-print version

DOI: $10.1007 / \mathrm{s} 10311-016-0582-2$

Accepted: $12^{\text {th }}$ September 2016

Published: $22^{\text {nd }}$ September 2016

Embargo period: 12 months

Unexpected removal of the most neutral cationic pharmaceutical in river waters

Alan D Tappin ${ }^{a}$, J Paul Loughnane ${ }^{b}$, Alan J. McCarthy ${ }^{b}$ and Mark F Fitzsimons ${ }^{a, *}$

${ }^{a}$ School of Geography, Earth and Environmental Sciences, Plymouth University, Plymouth,

PL4 8AA, UK

${ }^{\mathrm{b}}$ Microbiology Research Group, Institute of Integrative Biology, University of Liverpool,

Liverpool, L69 7ZB, UK

*Corresponding author

tel: $+44(0) 1752584572$

fax: +44 (0)1752 584710

email: mfitzsimons@plymouth.ac.uk 


\section{Abstract}

Contamination of surface waters by pharmaceuticals is now widespread. There are few data on their environmental behaviour, particularly for those which are cationic at typical surfacewater $\mathrm{pH}$. As the external surfaces of bacterio-plankton cells are hydrophilic with a net negative charge, it was anticipated that bacterio-plankton in surface-waters would preferentially remove the most extensively-ionised cation at a given $\mathrm{pH}$. To test this hypothesis, the persistence of four widely-used, cationic pharmaceuticals, chloroquine, quinine, fluphenazine and levamisole, was assessed in batch microcosms, comprising riverwater and bacterio-plankton, to which pharmaceuticals were added and incubated for 21 days. Results show that levamisole concentrations decreased by $19 \%$ in microcosms containing bacterio-plankton, and by $13 \%$ in parallel microcosms containing tripeptide as a priming agent. In contrast to levamisole, concentrations of quinine, chloroquine and fluphenazine were unchanged over 21 days in microcosms containing bacterio-plankton. At the river-water $\mathrm{pH}$, levamisole is $28 \%$ cationic, while quinine is $91-98 \%$ cationic, chloroquine $99 \%$ cationic, and fluphenazine $72-86 \%$ cationic. Thus the most neutral compound, levamisole, showed greatest removal, contradicting the expected bacterio-plankton preference for ionised molecules. However, levamisole was the most hydrophilic molecule, based on its octanolwater solubility coefficient (Kow). Overall the pattern of pharmaceutical behaviour within the incubations did not reflect the relative hydrophilicity of the pharmaceuticals predicted by the octanol-water distribution coefficient, Dow, suggesting that improved predictive power, with respect to modelling bioaccumulation, may be needed to develop robust environmental risk assessments for cationic pharmaceuticals.

Keywords: levamisole, quinine, chloroquine, fluphenazine, persistence, river 


\section{Introduction}

There are over 4000 pharmaceuticals available for human and veterinary use (Boxall et al. 2012). Following administration, unretained pharmaceuticals and any transformation products are excreted into surface waters, either directly or via treated and untreated wastewaters and biosolids. As a consequence, contamination of aquatic systems by pharmaceuticals is now extensive (Hughes et al. 2013; Cizmas et al. 2015). There remains, however, a marked lack of knowledge on the aquatic transport and fate of pharmaceuticals, and their biological effects (Boxall et al. 2012; Brooks et al. 2012; Kümmerer 2008; LaLone et al. 2014; Shore et al. 2014; Tijani et al. 2016). Effects of pharmaceuticals on terrestrial organisms have been reported, with one of the most publicised examples being the contribution of diclofenac residues to the almost total decline of the Gyps spp. vulture populations on the Indian sub-continent (Oaks et al. 2004). While such dramatic effects on aquatic organisms have not been reported to date, behavioural changes have been observed. For example, environmentally-measured concentrations of the benzodiazepines oxazepam and diazepam were shown to markedly alter the social behaviours of the wild European perch (Perca fluviatili) and adult zebrafish (Danio rerio), respectively (Brodin et al. 2013; Giacomini et al. 2016).

The prediction of Adverse Outcome Pathways (OECD 2013) for a pharmaceutical contaminant is, inter alia, dependent on understanding its mode of action (MoA) giving rise to one or more molecular-initiating events within an organism, either through specific ligandreceptor interactions or non-specific receptor interactions, which then leads to one or more adverse effects. Understanding the MoA in theory allows effects predictions to be extrapolated to other compounds with similar molecular characteristics, along with the ability to 'read across' to organisms from different taxonomic groups that share the same receptors (Hutchinson et al. 2013). Other important properties relevant to the manifestation of adverse 
effects include the persistence of, and hence exposure to, the pharmaceutical and the extent of accumulation within susceptible biota (Arnold et al. 2014).

For a given environmental loading, the degree of exposure of an organism to an pharmaceutical in surface waters is dependent on the extent of biological and physicochemical mechanisms on in situ, measured concentrations of the parent pharmaceutical, and any known transformation products. For example, in an assessment of the ability of riverine bacterio-plankton to transform the benzodiazepine, diazepam, and its photo-degradation product, 2-amino-5-chlorobenzophenone (ACB), diazepam was much more persistent than $\mathrm{ACB}$, which was mineralised to ammonium by the bacterio-plankton in all experiments (Tappin et al. 2014). This indicated that a removal of diazepam, and other benzodiazepines photodegrading to ACB (West \& Rowland 2012), could be effected even if the parent compound was not readily biotransformed. However, there is a lack of published studies on the role of microbes in the environmental cycling of pharmaceuticals, coupled with little discussion on biotic mechanisms of pharmaceutical removal.

In this study, the persistence of a range of commonly-prescribed human and veterinary pharmaceuticals in incubations containing riverine bacterio-plankton was examined. Chloroquine and quinine are quinoline derivatives used extensively in Asia, Africa and South America for the treatment of malaria, although they also have a range of other medical applications (Achan et al. 2011; Price et al. 2014); the MoA of their anti-malarial properties is not well understood (www.drugbank.ca). Chloroquine is excreted from humans either unaltered or as $\mathrm{N}$-desethyl chloroquine, and quinine unaltered or as 3-hydroxyquinine (Mirghani et al. 2003; Projean et al. 2003). Fluphenazine is a tri-fluorinated methyl phenothiazine derivative used to manage chronic psychoses including schizophrenia (Uchida et al. 2011); it is excreted in urine and faeces unchanged, or as 7-hydroxyfluphenazine, fluphenazine sulfoxide, and metabolite conjugates (McEvoy et al. 2004). Thus, these 
compounds will enter surface waters via wastewater discharge and irrigation, and leaching from sewage solids applied to land. Concerns regarding the presence of neuroendocrineactive chemicals in surface waters, and their potential biological effects, have been raised; particularly those pharmaceuticals, including fluphenazine, that act on widely conserved dopamine receptors (Villeneuve et al. 2010a; Villeneuve et al. 2010b). Levamisole is an imidazothiazole derivative used as a human and veterinary anthelmintic (Lanusse et al. 2009). It is also used as a human immuno-modulator and as an adulterant in cocaine (Bertol et al. 2011). For veterinary use, the compound is generally applied topically, thus enhancing its transport to surface waters.

There are no published data on the transformations of these pharmaceuticals in surface waters, although it has been predicted that lower than $1 \%$ of the quinine load entering a sewage treatment plant would be transformed (Jones et al. 2002). Furthermore, there are few data on their toxicity in the aquatic environment. Bioassays using the invertebrate Daphnia magna and alga Chlorella vulgaris suggested that chloroquine may be harmful to aquatic organisms (Zurita et al. 2005), while fluphenazine showed inhibitory effects on a range of bacterial species at concentrations of ca. 40 - $200 \mu \mathrm{mol} \mathrm{L}^{-1}$ (Dastidar et al. 1995). Levamisole has been cited as a high priority compound for detailed environmental risk assessment (Capleton et al. 2006; von der Ohe et al. 2011). These pharmaceuticals are all included in the World Health Organization's List of Essential Medicines (WHO 2015). Furthermore, they are ionisable molecules that can be protonated at surface water $\mathrm{pH}$, and there is a paucity of data on the fate of $\mathrm{pH}$-dependent cationic pharmaceuticals in these environments.

The potential problem of environmentally persistent pharmaceutical pollutants was recently recognised by the International Conference on Chemicals Management (ICCM 4, autumn 2015) as an Emerging Policy Issue of the Strategic Approach to International 
Chemicals Management (http://www.saicm.org/). Furthermore, 3 pharmaceuticals were included on the European Union (EU) watch list of March 2015 (EU 2015), with a view to proposing statutory Environmental Quality Standards within the EU Water Framework Directive; while the latest United States Environmental Protection Agency draft Contaminant Candidate List (CCL4) includes 8 pharmaceuticals and 2 pharmaceutical-precursors (https://www.epa.gov/ccl/chemical-contaminants-ccl-4), including quinoline. These regulatory concerns reflect the tension between the need for medicines to maintain and improve health and managing their potential environmental impact. 


\section{Materials and methods}

The full details of the design, testing and validation of the incubation procedure have been reported previously (Tappin et al. 2012; Tappin et al. 2014).

\subsection{Media and chemicals}

River water required for the microcosms and preparation of bacterio-plankton inocula were collected from Gunnislake, at the tidal limit of the River Tamar located in southwest England, UK. The river drains a rural, agriculture-dominated, catchment, and water quality is generally good (Tappin et al. 2012; Tappin et al. 2014), although the river and its catchment are impacted by historical metal mining activity. River turbidity is low (generally lower than $15 \mathrm{mg} \mathrm{L}^{-1}$ ) and the oxygen saturation is high (generally > $90 \%$ ) at the tidal limit, while the mean $\mathrm{pH}$ is 7.4 (Environment Agency, unpublished data). The pharmaceuticals used in the study were purchased as levamisole hydrochloride, quinine hemisulphate monohydrate, chloroquine diphosphate and fluphenazine hydrochloride (Sigma Aldrich, AR grade). A tripeptide comprising the amino acids glycine, leucine and tyrosine (GLY; Sigma Aldrich, $\geq 98$ $\%$ purity), and representing labile organic matter, was also used to assess a priming effect on the bacterio-plankton population (Guenet et al. 2010) in the incubations involving levamisole only. Stock solutions of these compounds were made up in prepared incubation water and stored at $4{ }^{\circ} \mathrm{C}$ in the dark prior to use. Structural details of the compounds are given in Table 1.

\subsection{Microcosm experiments}

\section{Preparation of incubation water}

River water was filtered (GF/F; $0.7 \mu \mathrm{m}$ nominal pore diameter) to remove suspended particles, passed through a strong anion-exchange resin (Dowex ${ }^{\circledR}$ X-100, 200 mesh; water flow rate $80 \mathrm{~mL} \mathrm{~h}^{-1}$ ) to remove nitrate, $\mathrm{UV}$-irradiated ( $400 \mathrm{~W}$ medium pressure $\mathrm{Hg}$ lamp, $6 \mathrm{~h}$ ) to remove dissolved organic carbon (DOC) and then re-filtered through a $0.2 \mu \mathrm{m}$ filter 
membrane (Whatman Anodisc 47, aluminium oxide) to remove any remaining particulate matter. These processes reduced nitrate and DOC to concentrations which ensured that alternative carbon and nitrogen substrates were, as far as possible, removed and that the river water matrix was compatible with direct analysis of samples by electrospray ionisation-mass spectrometry (ESI-MS). As a final step, the water was sterilised by autoclaving $\left(115^{\circ} \mathrm{C}, 15\right.$ $\min )$.

Preparation of the inoculum

The bacterial inoculum was prepared using river water collected within $24 \mathrm{~h}$ prior to introduction in to the microcosm. This water was filtered through a $1.6 \mu \mathrm{m}$ pore diameter membrane (combusted GF/A) to remove zooplankton and particle-bound bacterio-plankton (Ainsworth \& Goulder 1998) and then re-filtered through a $0.2 \mu \mathrm{m}$ pore diameter membrane filter (Whatman Anodisc 47). The bacterio-plankton retained on the membrane was resuspended in a small volume of the $0.2 \mu \mathrm{m}$ filtered water to provide the inoculum, which was then added to the pre-treated river water to produce a final, representative bacterioplankton concentration.

\section{Incubation experiments}

Incubation water $(60 \mathrm{~mL})$ was transferred to a $125 \mathrm{~mL}$ screw-capped amber glass bottle to which was added $30-60 \mu \mathrm{L}$ of stock pharmaceutical solution and $1 \mathrm{~mL}$ of the bacterio-plankton inoculum. Starting concentrations of the compounds were ca. 15-30 $\mu \mathrm{mol}$ $\mathrm{L}^{-1}$. Control microcosms of prepared river water containing bacterio-plankton inoculum only and the pharmaceuticals only were also set up to account for sorption effects and to investigate the effects of the pharmaceuticals on the bacterio-plankton communities. In a separate microcosm, $30 \mu \mathrm{mol} \mathrm{L}{ }^{-1}$ of GLY was added with levamisole. The $125 \mathrm{~mL}$ bottles were loosely-capped, placed in a re-sealable plastic bag and transferred to an orbital shaker. Microcosms were prepared in duplicate at ambient temperature in the dark. An incubation 
time of 21 days was selected to reflect the river water transit time in the Tamar catchment. At day 0 and day 21, incubated samples were filtered using combusted GF/F filters and subsamples collected for analyses.

\subsection{Chemical and microbiological analyses}

The pharmaceuticals were analysed by ESI-MS using a Finnegan MAT LCQ MS, a quadrupole ion trap mass spectrometer with an external source atmospheric pressure interface capable of electro-spray ionisation. Solutions were introduced into the instrument by direct injection from a $250 \mu \mathrm{L}$ Hamilton syringe at a rate of $3 \mu \mathrm{L} \mathrm{min}^{-1}$. Prior to injection, each sample and standard was diluted 1:1 with methanol amended with $0.1 \%(\mathrm{v} / \mathrm{v})$ formic acid. The signal sensitivity for each pharmaceutical, in positive-ion mode, was optimised by adjustment of instrumental parameters using in-built tuning procedures. Ion counts were integrated for $2 \mathrm{~min}$, and $5 \times 2 \mathrm{~min}$ replicates were recorded per sample. Ion count stability was followed in real-time via single ion monitoring. Quantitation of the analyte was achieved by generating an external standard calibration curve on each analytical day and bracketing individual samples with a drift calibration standard to account for variations in instrumental sensitivity. Changes in sensitivity were accounted for using an algorithm developed for automated nutrient analysis (Skalar Analytical BV 2004); in this implementation baseline drift was assumed unimportant (equation 1).

$\mathrm{U}^{\prime}{ }_{(\mathrm{n})}=\left(\mathrm{U}_{(\mathrm{n})} *(\mathrm{D} 1 /((((\mathrm{D}(\mathrm{b})-\mathrm{D}(\mathrm{a})) /(\mathrm{b}-\mathrm{a})) *(\mathrm{n}-\mathrm{a}))+\mathrm{D}(\mathrm{a}))) \quad\right.$ equation 1 $\mathrm{U}_{(\mathrm{n})}=$ drift corrected ion count for sample $\mathrm{n}, \mathrm{U}_{(\mathrm{n})}=$ ion count for sample $\mathrm{n}, \mathrm{D} 1=$ ion count of the first drift standard, $\mathrm{D}(\mathrm{a})=$ ion count of the preceding drift standard, $\mathrm{D}(\mathrm{b})=$ ion count of the following drift standard, $\mathrm{n}=$ sample number, $\mathrm{a}=$ sample number of preceding drift standard and $b=$ sample number of following drift standard. Standards were matrix-matched with the water used for the incubations. The identification of $\mathrm{m} / \mathrm{z}$ values for potential biotransformation products was informed by the EAWAG Biocatalysis and Biodegradation 
Database (EAWAG-BDD; Ellis \& Wackett 2012), now redesigned as enviPath (Wicker et al. 2016). Nitrate + nitrite and orthophosphate were determined by colorimetry with a precision of lower than $1 \%$ (Skalar Analytical BV, 2004) and ammonium by $o$-phthaldialdehyde fluorescence with a precision of $4 \%$ (Holmes et al. 1999).

Viable counts of bacterio-plankton were determined using $100 \mu \mathrm{L}$ aliquots from the incubations. These were diluted in phosphate-buffered saline solution and $100 \mu \mathrm{L}$ of each dilution spread on half strength Luria Bertani agar (Merck, Germany) and incubated at $30{ }^{\circ} \mathrm{C}$ for two days. Colonies were enumerated as colony forming units (cfu) $\mathrm{mL}^{-1}$ of the original suspensions. The extraction of DNA and PCR amplification of 16S ribosomal RNA genes for bacterio-plankton community analysis were undertaken on cells retained on a $0.2 \mu \mathrm{m}$ membrane filter. The retained cells were disrupted in a Hybaid Ribolyser ${ }^{\mathrm{TM}}$ Cell Disruptor, and the DNA was subsequently extracted into hexadecyltrimethylammonium bromide and phenol-chloroform-isoamyl alcohol, followed by resuspension in $50 \mu \mathrm{L}$ nuclease-free water (Griffiths et al. 2000). Nested PCR amplifications were performed on these samples using Super Taq DNA polymerase (HT Biotech Ltd, UK) and G-Storm thermal cyclers (GRI, UK). DNA amplification was undertaken in a $50 \mu \mathrm{L}$ sample using $1 \mu \mathrm{mol} \mathrm{L}^{-1}$ of the universal primers for eubacterial 16S rRNA genes (27f and 1492 $)$ (Lane 1991) with 1 unit super Taq DNA polymerase. The amplified DNA fragments were re-amplified using forward primer 341 and reverse primer 907 (Muyzer et al. 1995). Denaturing gradient gel electrophoresis (DGGE) analysis (Muyzer et al. 1993) was performed on GC-clamped products of the second PCR amplification using the Bio-Rad D-code system to separate DNA on a $8 \%$ polyacrylamide gel in Tris acetate EDTA buffer ( $\mathrm{pH} 8.0)$ with a 20-60 \% denaturant gradient, in which $100 \%$ denaturant was 7 molar urea amended with $40 \%$ formamide (Muyzer et al. 1993). Electrophoresis was performed at $60{ }^{\circ} \mathrm{C}$, run at $60 \mathrm{~V}(16 \mathrm{~h})$ and the DNA banding 
visualised using Sybr Green I stain (Lonza Rockland, USA) with detection and image capture on a Storm 860 Molecular Imager (Molecular Dynamics, UK). 


\section{Results and discussion}

\subsection{Bacterio-plankton incubations}

The abiotic control studies showed that none of the compounds was lost through sorption to the walls of the incubation bottles or through chemical degradation, during the experiments. The bacterio-plankton inocula were viable throughout the incubation period, as concentrations of colony forming units increased by an order of magnitude in the microcosms containing pharmaceuticals (from lower than $10,000 \mathrm{cfu} \mathrm{mL}^{-1}$ at day 0 to $82,000 \mathrm{cfu} \mathrm{mL}^{-1}$ for levamisole and 220,000 $\mathrm{cfu} \mathrm{mL}^{-1}$ for fluphenazine at day 21). There was also a large increase in ammonium concentrations (from 0.7 to $68.0 \mu \mathrm{mol} \mathrm{NH}_{4}{ }^{+}-\mathrm{N} \mathrm{L}^{-1}$ ) after 21 days in the levamisole microcosms to which the GLY peptide had been added (Fig. 1), a further indication of bacterio-plankton mineralisation of dissolved organic matter. $\mathrm{The}^{\mathrm{NH}_{4}}{ }^{+}$ produced represented ca. $74 \%$ of the peptide nitrogen and its degradation was consistent with previous results for such incubations containing GLY only or GLY plus pharmaceutical (Tappin et al. 2012; Tappin et al. 2014). In addition, our previous results, using clone libraries, showed that bacterio-plankton sampled from the Tamar water microcosms contained Gram negative ( $\alpha$-proteobacteria, $\beta$-proteobacteria) and Gram positive (Firmicutes) groups previously reported for freshwaters, which are capable of biotransforming xenobiotic contaminants (Tappin et al. 2014).

\subsection{Persistence of pharmaceuticals}

Between days 0 and 21, the concentration of levamisole decreased from $33.2 \mu \mathrm{mol} \mathrm{L}{ }^{-1}$ to $26.9 \mu \mathrm{mol} \mathrm{L} \mathrm{L}^{-1}(19 \%$ removal) in the biotic incubation (Fig. 1; t-test, $\mathrm{p}<0.001, \mathrm{n}=10$ ), and to $28.6 \mu \mathrm{mol} \mathrm{L} \mathrm{L}^{-1}$ (13\% removal) in the biotic incubation with added peptide (Fig. 1a; $\mathrm{t}$ test, $\mathrm{p}=0.002, \mathrm{n}=10)$. While solid - solution partition coefficients $\left(\mathrm{K}_{\mathrm{d}}\right)$ are not available for levamisole, $\mathrm{K}_{\mathrm{d}} \mathrm{S}$ for ionisable pharmaceuticals are generally relatively low. The measured decreases in dissolved levamisole concentrations were almost certainly due to uptake into the 
bacterio-plankton, rather than simple sorption to cell surface components as the suspended solids concentration was lower than $1 \mathrm{mg} \mathrm{L}^{-1}$ in the incubations. A DGGE fingerprinting of the amplified 16S rRNA marker genes of the bacterio-plankton communities incubated with and without levamisole, showed that species composition (genotype) profiles were similar under all incubation conditions. In contrast to levamisole, the concentrations of quinine, chloroquine and fluphenazine remained constant in the microcosms over the 21 day period (Fig. 2), indicating that these pharmaceuticals were persistent.

Passive uptake of low molecular mass (lower than 500) compounds into prokaryotic Gram negative and positive bacterio-plankton is more likely to occur with hydrophilic moieties, as the outer cell walls of these bacterio-plankton are hydrophilic (Hancock \& Bell 1988; Nikaido \& Vaara 1985). They also have a net negative charge which, in principle, should favour the electrostatic sorption of positively-charged compounds. The octanol-water solubility coefficients $\left(\log \mathrm{K}_{\mathrm{ow}}\right)$ of the pharmaceuticals in this study indicate that levamisole was the most hydrophilic (Table 2). Their acid dissociation constants $\left(\mathrm{pK}_{\mathrm{a}}\right)$, on the other hand, indicate that fluphenazine, chloroquine and quinine would be extensively positively ionised at $\mathrm{pH} 7.4$, the mean $\mathrm{pH}$ of Tamar river water (Table 2), potentially promoting sorption to the cells by electrostatic attraction, while increasing their inherent water solubility (Gulde et al. 2014; Rendal et al. 2011a). These physico-chemical characteristics can be combined to yield a net hydrophilicity, the octanol-water distribution coefficient $(\log ) \mathrm{D}_{\mathrm{ow}}$, which may better explain any observed loss of pharmaceutical from solution (Manallack et al. 2013; Warhurst et al. 2003). For a monoprotic base (e.g. levamisole), the net hydrophilicity can be calculated from equation 2 :

$\left.\log \mathrm{D}_{\mathrm{ow}}=\log \mathrm{K}_{\mathrm{ow}}-\log \left[1+10^{(\mathrm{pK}}-\mathrm{pH}\right)\right]$ equation 2 For a diprotic, basic pharmaceutical (e.g. quinine, chloroquine and fluphenazine), equation 3 is used, where $\mathrm{pK}_{\mathrm{a} 1}>\mathrm{pK}_{\mathrm{a} 2}$ : 


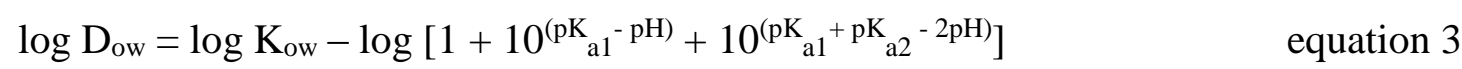

The calculated $\log \mathrm{D}_{\mathrm{ow}}$ values at $\mathrm{pH} 7.4$ are given in Table 2. In principle, the smaller the value, the more hydrophilic is the compound, and thus the easier for uptake into the cells of the bacterio-plankton present in the current study. The results of these calculations suggest that chloroquine is the most hydrophilic pharmaceutical, fluphenazine the least, and levamisole and quinine intermediate, but this did not correspond with the measured loss of pharmaceutical from solution in this study. Similarly poor correlations between estimated log $\mathrm{D}_{\mathrm{ow}}$ and the biotransformation of the basic pharmaceuticals atenolol, ifenprodil and propranolol in batch incubations with river water have been reported elsewhere (Yamamoto et al. 2009). The lack of predictive power using $\mathrm{D}_{\text {ow }}$ may be attributed to poorly constrained $\log \mathrm{K}_{\mathrm{ow}}$ and / or $\mathrm{pK}_{\mathrm{a}}$ values, particularly for basic pharmaceuticals (ECETOC 2013; Kah \& Brown 2008; Manallack et al. 2013). Additionally, it may contribute to our lack of insight to the importance of hydrophobic partitioning of ionisable pharmaceuticals relative to possible mechanisms of hydrophilic interaction (ECETOC 2013; Manallack et al. 2013). Whatever the explanation, an important observation to be drawn from the current study is that it was the most hydrophilic pharmaceutical, based on $\log \mathrm{K}_{\mathrm{ow}}$ alone, and least ionised, based on $\mathrm{pK}_{\mathrm{a}}$ alone, that was removed from river water containing bacterio-plankton.

Studies of pharmaceutical uptake by eukaryotes (animals and plants) have reported that it is the non-ionised forms of the pharmaceutical that show greatest partitioning into cells (Rendal et al. 2011b; Warhurst et al. 2003) while recently, the extent of bacterial transformation of pharmaceuticals incubated with sewage sludge was shown to be generally proportional to the fraction of un-ionised, neutral, species present (Gulde et al. 2014). It may be concluded, therefore, that of the total pharmaceutical pool present, it is the non-specific biotransformation of the neutral or weakly-ionised pharmaceutical fraction that is most likely to occur in surface waters, irrespective of cell type. 
The loss of levamisole did not result in identifiable biotransformation products detected by ESI-MS (Fig. 1), even though these were predicted from the EAWAG-BBD, via initial de-alkylation of the tertiary amine to yield secondary and primary amines. Indeed, the dominance of the observed de-alkylation of pharmaceuticals containing a tertiary amine has been reported recently (Gulde et al. 2016). The $\mathrm{m} / \mathrm{z}$ values of the predicted transformation products are marked in Figure 1, and did not correspond with detected peaks. This suggests that, if biotransformation molecules were produced, they were not released into solution but were further metabolised rapidly, or were present at concentrations below the limit of detection under these conditions.

The 3 pharmaceuticals that were persistent all contain at least one tertiary amine, while chloroquine also contains a secondary amine group (Table 1). As noted above, the EAWAG-BBD predicts bacterio-plankton alteration of these functional groups via dealkylation (Gulde et al. 2016). In contrast, the mono-N-substituted heterocyclic ring in the quinolone derivatives quinine and chloroquine is more difficult to decompose (Alexander 1999), though heterocyclic ring opening of quinoline by bacteria has been reported (Griese et al. 2006). The EAWAG-BDD does not take into account the polarity of the molecule under consideration, however, and the persistence of these pharmaceuticals is thus probably attributable to their extensive (positive) ionisation under the incubation conditions and lack of cell uptake; the presumed electrostatic attraction appeared to have no measurable influence (Gulde et al. 2014; Rendal et al. 2011a; Rendal et al. 2011b). While quantitative estimates of the relative speeds of cell uptake by ionised and non-ionised basic pharmaceuticals are lacking, equivalent studies on acidic moieties show uptake speeds $10^{3}-10^{4}$ lower for the ionic forms relative to the neutral species (Rendal et al. 2011b). 


\subsection{Investigation of a priming effect}

The addition of labile organic matter (LOM) to accelerate bacterio-plankton biotransformation of more persistent organic matter is known as the priming effect, although there are few systematic studies of this phenomenon in aquatic systems (Gontikaki et al. 2013; Guenet et al. 2014). The presence of LOM, as wastewater effluent DOC added at relatively high concentrations, has been proposed to enhance pharmaceutical loss from river and estuarine coastal waters (Benotti \& Brownawell 2009; Lim et al. 2008), but reports of decreased biotransformation of the target molecule, or no change, has also been reported and a range of mechanisms has been invoked to explain these varied outcomes (Bengtsson et al. 2014). In the current work, levamisole was incubated with the peptide as LOM - equivalent to ca. $500 \mu \mathrm{mol} \mathrm{C} \mathrm{L}-1$ and ca. $90 \mu \mathrm{mol} \mathrm{N} \mathrm{L}{ }^{-1}$, concentrations which are typical of UK rural and semi-rural rivers, and of the same magnitude as the concentrations of DOC reported to enhance pharmaceutical loss in surface waters (Benotti \& Brownawell 2009; Lim et al. 2008). While levamisole concentrations decreased in the presence of bacterio-plankton and LOM, the loss was not significantly different to that observed in parallel incubations without added LOM ( $\mathrm{t}$-test, $\mathrm{p}=0.142, \mathrm{n}=11$ ). This outcome indicates that the biotransformation of levamisole occurs in surface waters, but that there would not necessarily be a priming effect, constraining transformation of the molecule to lower than $20 \%$ of the total load. 


\subsection{Environmental implications}

The data from this study suggest that all of the molecules examined would be stable, to varying degrees, in surface waters, at least with respect to biotransformation by riverine bacterio-plankton. This finding, coupled to their probable continual loading to the environment, would suggest they may be persistent or, in the case of levamisole, pseudopersistent in surface waters. While it is difficult to contextualise this outcome in relation to potential environmental impacts on aquatic organisms due to the absence of data on other ameliorating processes (e.g. photo-degradation or sorption to sediments), it may be hypothesised that, individually, these compounds will not inflict acute toxic effects at the concentrations anticipated. This assessment is supported by the viability of the bacterioplankton communities shown in this work, coupled to the lack of community succession throughout the incubations for all the pharmaceuticals (indicated by the consistency of the DGGE fingerprint patterns across the experiments). Nevertheless, environmental implications arising from continual and chronic exposure of aquatic organisms to these pharmaceuticals, either as single entities or as mixtures, remain to be addressed.

Malaria is endemic in the low and low-middle income countries (LLMIC) of Asia, Africa and central and South America (http://www.cdc.gov/malaria/about/distribution.html) and it is in these regions that use of chloroquine and quinine to combat malaria are likely to be highest, and contamination of wastewater with these pharmaceuticals most frequent. Many LLMIC make extensive use of wastewater for the irrigation of agricultural and horticultural crops, particularly in southern Asia and western South America (Lautze et al. 2014; Lees et al. 2016). The implication is that these quinolones will be continually added to surface waters, with possibly unforseen environmental consequences given their poorly understood modes of action. 
Dopamine receptors occur in almost all vertebrate and invertebrate animals (Barron et al. 2010), while some bacteria and many plant species synthesise dopamine. Unlike in animals, the function(s) of, and receptor(s) for, dopamine in plants has yet to be elucidated (Kulma \& Szopa 2007). The presence in surface waters of dopamine inhibitors like fluphenazine and other frequently prescribed behaviour-altering psychiatric and antidepressant pharmaceuticals is a cause for concern. It has been reported that the antipsychotic pharmaceutical haloperidol, a dopamine inhibitor, may affect the behaviour of some fish species (Villeneuve et al. 2010a; Villeneuve et al. 2010b), while benzodiazepenes also elucidate behavioural changes in fish (Brodin et al. 2013; Giacomini et al. 2016). If these groups of neurotransmitters are persistent in the aquatic environment, then unanticipated and undesired impacts may emerge (Brodin et al. 2014).

The inability to accurately model the bioaccumulation of ionisable pharmaceuticals using established physico-chemical metrics, including the compounds examined in this study but also more widely, will prevent the development of a robust and comprehensive risk assessment of pharmaceutical fate and impact in aquatic systems. Given the projected increases in pharmaceutical use across the globe (IMS 2015) it would appear prudent to significantly improve our predictive capability with respect to bioaccumulation. 


\section{Conclusions}

This study found that microbially-mediated pharmaceutical loss from river water containing bacterio-plankton occurred, to an extent, but only for a pharmaceutical expected to be largely un-ionised under the conditions of the experiment. No losses occurred, under similar conditions, for the three pharmaceuticals expected to be ionised to a much greater degree. This observation is consistent with the paradigm that, in the absence of specific uptake mechanisms, small non-polar compounds are more easily sorbed by living cells, compared to small polar moieties. The contrasting net hydrophilic values calculated for the pharmaceuticals indicated that the explanation is less straightforward, although some of the data underpinning the calculations may not be well constrained. Thus, an improved predictive bacterio-plankton cell uptake capability for ionisable cationic pharmaceuticals in aquatic systems would appear to be imperative.

Although studies of pharmaceuticals in surface waters of high income countries is now in its fourth decade, their remains little systematic understanding of pharmaceutical transport, fate and impact. This is all the more concerning for lower income countries, where pharmaceutical use is forecast to increase significantly in the foreseeable future, with attendant increased losses of pharmaceuticals to the environment, and losses in many cases fuelled by the aspiration for the increased use of waste water for the irrigation of agricultural and horticultural crops. This will only enhance the widespread diffuse contamination of aquatic systems by pharmaceuticals, with potential unforeseen consequences. 


\section{Acknowledgments}

This work was funded by the UK Natural Environment Research Council (grant NE/E006302/1) and the Seale-Hayne Educational Trust of Plymouth University. We are grateful to Dr Clare Redshaw (PU) for advice on the use of the Finnegan MAT LCQ mass spectrometer and Dr Claire Williams (PU) for help with the inorganic nutrient analyses. The microcosm studies were undertaken in an ISO 9000:2001 accredited laboratory. 


\section{References}

Achan J, Talisuna A, Erhart A, Yeka A, Tibenderana J, Baliraine F, Rosenthal P, D'Alessandro U (2011) Quinine, an old anti-malarial drug in a modern world: role in the treatment of malaria. Malaria Journal 10: 144-155

Ainsworth AM, Goulder R (1998) Microbial organic-nitrogen transformations along the Swale-Ouse river system, Northern England. Science of the Total Environment 210/211: 329-355

Alexander M (1999) Biodegradation and Bioremediation, 2nd ed. Academic Press,

Arnold KE, Brown AR, Ankley GT, Sumpter JP (2014) Medicating the environment: assessing risks of pharmaceuticals to wildlife and ecosystems. Philosophical Transactions of the Royal Society of London B: Biological Sciences 369: 20130569

Barron AB, Søvik E, Cornish JL (2010) The roles of dopamine and related compounds in reward-seeking behavior across animal phyla. Frontiers in Behavioral Neuroscience 4: 163

Bengtsson MM, Wagner K, Burns NR, Herberg ER, Wanek W, Kaplan LA, Battin TJ (2014) No evidence of aquatic priming effects in hyporheic zone microcosms. Scientific Reports 4: 5187-5192

Benotti MJ, Brownawell BJ (2009) Microbial degradation of pharmaceuticals in estuarine and coastal seawater. Environmental Pollution 157: 994-1002

Bertol E, Mari F, Milia MG, Politi L, Furlanetto S, Karch SB (2011) Determination of aminorex in human urine samples by GC-MS after use of levamisole. Journal of Pharmaceuticals and Biomedicines 55: 1186-1189

Boxall AB, Rudd MA, Brooks BW et al. (2012) Pharmaceuticals and personal care products in the environment: what are the big questions? Environmental Health Perspectives 120: 1221-1229

Brodin T, Fick J, Jonsson M, Klaminder J (2013) Dilute concentrations of a psychiatric drug alter behavior of fish from natural populations. Science 339: 814-815

Brodin T, Piovano S, Fick J, Klaminder J, Heynen M, Jonsson M (2014) Ecological effects of pharmaceuticals in aquatic systems - impacts through behavioural alterations. Philosophical Transactions of the Royal Society of London B: Biological Sciences 369: 20130580

Brooks BW, Covaci A, Barcelo D (2012) Pharmaceuticals and illicit drugs in aquatic systems. Science of the Total Environment, Virtual Special Issue.http://www.journals.elsevier.com/science-of-the-totalenvironment/virtual-specialissues/pharmaceuticals-and-illicit-drugs-in-aquatic-systems

Capleton AC, Courage C, Rumsby P, Holmes P, Stutt E, Boxall ABA, Levy LS (2006) Prioritising veterinary medicines according to their potential indirect human exposure and toxicity profile. Toxicology Letters 163: 213-223

Cizmas L, Sharma VK, Gray CM, McDonald TJ (2015) Pharmaceuticals and personal care products in waters: occurrence, toxicity, and risk. Environmental Chemistry Letters 13: 381-394

Dastidar SG, Chaudhury A, Annadurai S, Roy S, Mookerjee M, Chakrabarty AN (1995) In vitro and in vivo antimicrobial action of fluphenazine. Journal of Chemotherapy 7: 201206

ECETOC (2013) Environmental Exposure Assessment of Ionisable Organic Compounds. Technical report No. 123. http://www.ecetoc.org/wp-content/uploads/2014/08/ECETOCTR-123-Environmental-risk-assessment-of-ionisable-compounds.pdf (accessed 18th July 2016) 
Ellis LBM, Wackett LP (2012) Use of the University of Minnesota Biocatalysis/Biodegradation Database for study of microbial degradation. Microbial Informatics and Experimentation 2: 1-11

EU (2015) COMMISSION IMPLEMENTING DECISION (EU) 2015/495 of 20 March 2015 establishing a watch list of substances for Union-wide monitoring in the field of water policy pursuant to Directive 2008/105/EC of the European Parliament and of the Council. http://eur-lex.europa.eu/legal content/EN/TXT/PDF/?uri=CELEX:32015D0495\&from=EN (accessed 18 ${ }^{\text {th }}$ July, 2016)

Giacomini ACVV, Abreu MS, Giacomini LV, Siebel AM, Zimerman FF, Rambo CL, Mocelin R, Bonan CD, Piato AL, Barcellos LJG (2016) Fluoxetine and diazepam acutely modulate stress induced-behavior. Behavioural Brain Research 296: 301-310

Gontikaki E, Thornton B, Huvenne VAI, Witte U (2013) Negative priming effect on organic matter mineralisation in NE Atlantic slope sediments. Plus One 8: e67722

Griese JJ, Jakob RP, Schwarzinger S, Dobbek H (2006) Xenobiotic reductase A in the degradation of quinoline by Pseudomonas putida 86: function, structure and mechanism of 8-hydroxycoumarin reduction. Journal of Molecular Biology 361: 140-152

Griffiths RI, Whiteley AS, O'Donnell AG, Bailey MJ (2000) Rapid method for co-extraction of DNA and RNA from natural environments for analysis of ribosomal DNA- abd RNAbased microbial community composition. Applied and Environmental Microbiology 66: $5488-5491$

Guenet B, Danger M, Abbadie L, Lacroix G (2010) Priming effect: bridging the gap between terrestrial and aquatic ecology. Ecology 91: 2850-2861

Guenet B, Danger M, Harrault L, Allard B, Jauset-Alcala M, Bardoux G, Benest D, Abbadie L, Lacroix G (2014) Fast mineralization of land-born $C$ in inland waters: first experimental evidences of aquatic priming effect. Hydrobiologia 721: 35-44

Gulde R, Helbling DE, Scheidegger A, Fenner K (2014) pH-dependent biotransformation of ionizable organic micropollutants in activated sludge. Environmental Science \& Technology 48: 13760-13768

Gulde R, Meier U, Schymanski EL, Kohler H-PE, Helbling DE, Derrer S, Rentsch D, Fenner $\mathrm{K}$ (2016) Systematic exploration of biotransformation reactions of amine-containing micropollutants in activated sludge. Environmental Science \& Technology 50: 2908-2920

Hancock REW, Bell A (1988) Antibiotic uptake into gram-negative bacteria. European Journal of Microbiology and Infectious Diseases 7: 713-720

Holmes RM, Aminot A, Kérouel R, Hooker BA, Peterson BJ (1999) A simple and precise method for measuring ammonium in marine and freshwater ecosystems. Canadian Journal of Fisheries and Aquatic Sciences 56: 1801-1808

Hughes SR, Kay P, Brown LE (2013) Global synthesis and critical evaluation of pharmaceutical data sets collected from river systems. Environmental Science \& Technology 47: 661-677

Hutchinson TH, Lyons BP, Thain JE, Law RJ (2013) Evaluating legacy contaminants and emerging chemicals in marine environments using adverse outcome pathways and biological effects-directed analysis. Marine Pollution Bulletin 74: 517-525

IMS (2015) Global medicines use in 2020: outlook and implications. Institute for Healthcare Informatics, November 2015. http://www.imshealth.com/en/thoughtleadership/ims-institute/reports/global-medicines-use-in-2020

Jones OAH, Voulvoulis N, Lester JN (2002) Aquatic environmental assessment of the top 25 English prescription pharmaceuticals. Water Research 36: 5013-5022

Kah M, Brown CD (2008) Log D: lipophilicity for ionisable compounds. Chemosphere 72: 1401-1408 
Kulma A, Szopa J (2007) Catecholamines are active compounds in plants. Plant Science 172: 433-440

Kümmerer K (2008) Pharmaceuticals in the Environment: Sources, Fate, Effects and Risks 3rd ed. Springer-Verlag, Berlin

LaLone CA, Berninger JP, Villeneuve DL, Ankley GT (2014) Leveraging existing data for prioritization of the ecological risks of human and veterinary pharmaceuticals to aquatic organisms. Philosophical Transactions of the Royal Society of London B: Biological Sciences 369: 20140022

Lane DJ (1991) 16S/23S rRNA sequencing. In: Stackebrandt E \& Goodfellow M (eds) Nucleic Acid Techniques in Bacterial Systematics. John Wiley \& Sons, New York.

Lanusse CE, Alvaréz LI, Sallovitz JM, Mottier ML, Sanchez Bruni SF (2009) Antinematodal drugs. In: Riviere JE \& Papich MG (eds) Veterinary Pharmacology and Therapeutics 9th ed. Wiley-Blackwell, Iowa

Lautze J, Stander E, Drechsel P, da Silva AK, Keraita B (2014) Global experience in water reuse. In: CGIAR Research Program on Water, Land and Ecosystems (WLE). International Water Management Institute (IWMI), Colombo, Sri Lanka, p 31. Resource Recovery and Reuse Series 4. doi:10.5337/2014.209

Lees K, Fitzsimons M, Snape J, Tappin A, Comber S (2016) Pharmaceuticals in soils of lower income countries: physico-chemical fate and risks from wastewater irrigation. Environ Int 94:712-723

Lim M-H, Snyder SA, Sedlak DL (2008) Use of biodegradable dissolved organic carbon (BDOC) to assess the potential for transformation of wastewater-derived contaminants in surface waters. Water Research 42: 2943-2952

Manallack DT, Prankerd RJ, Yuriev E, Oprea TI, Chalmers DK (2013) The significance of acid/base properties in drug discovery. Chemical Society Reviews 42: 485-496

McEvoy GK, Miller J, Litvak K (Eds) (2004) American Hospital (AHFS) Drug Information 2004. Bethesda: American Society of Health-System Pharmacists

Mirghani RA, Ericsson O, Tybring G, Gustafsson LL, Bertilsson L (2003) Quinine 3hydroxylation as a biomarker reaction for the activity of CYP3A4 in man. European Journal of Clinical Pharmacology 59: 23-28

Muyzer G, De Waal EC, Uitterlinden AG (1993) Profiling of complex microbial populations by denaturing gradient gel electrophoresis of polymerase chain reaction-amplified genes coding for 16S rRNA. Applied and Environmental Microbiology 59: 695-700

Muyzer G, Teske A, Wirsen CO, Jannasch HW (1995) Phylogenic relationship of Thiomicrospira species and their identification in deep-sea hydrothermal vent samples by denaturing gradient gel electrophoresis of $16 \mathrm{~S}$ rRNA fragments. Archives of Microbiology 164: 165-172

Nikaido H, Vaara M (1985) Molecular basis of bacterial outer membrane permeability. Microbiological Reviews 49: 1-32

Oaks JL, Gilbert M, Virani MZ, Watson RT, Meteyer CU, Rideout BA, Shivaprasad HL, Ahmed S, Iqbal Chaudhry MJ, Arshad M, Mahmood S, Ali A, Ahmed Khan A (2004) Diclofenac residues as the cause of vulture population decline in Pakistan. Nature 427: 630-633

OECD (2013) Guidance document on developing and assessing adverse outcome pathways. In: Environment, health and safety publications series on testing and assessment no. 184,Paris.http://www.oecd.org/officialdocuments/publicdisplaydocumentpdf/?cote=env/ jm/mono(2013)6\&doclanguage $=$ en

Price RN, von Seidlein L, Valecha N, Nosten F, Baird JK, White NJ (2014) Global extent of chloroquine-resistant Plasmodium vivax: a systematic review and meta-analysis. Lancet Infectious Diseases 14: 982-991 
Projean D, Baune B, Farinotti R, Flinois JP, Beaune P, Taburet AM, Ducharme J (2003) In vitro metabolism of chloroquine: identification of CYP2C8, CYP3A4, and CYP2D6 as the main isoforms catalyzing $\mathrm{N}$-desethylchloroquine formation. Drug Metabolism and Disposition 31: 748-754

Rendal C, Ole Kusk K, Trapp S (2011a) The effect of pH on the uptake and toxicity of the bivalent weak base chloroquine tested on Salix viminalis and Daphnia magna. Environmental Toxicology and Chemistry 30: 354-359

Rendal C, Ole Kusk K, Trapp S (2011b) Optimal choice of $\mathrm{pH}$ for toxicity and bioaccumulation studies of ionizing organic chemicals. Environmental Toxicology and Chemistry 30: 2395-2406

Shore RF, Taggart MA, Smits J, Mateo R, Richards NL, Fryday S (2014) Detection and drivers of exposure and effects of pharmaceuticals in higher vertebrates. Philosophical Transactions of the Royal Society of London B: Biological Sciences 369: 20130570

Skalar Analytical BV (2004) Skalar SanPlus Analyzer General Information. PO Box 3237 4800 DE Breda The Netherlands

Tappin AD, Loughnane JP, McCarthy AJ, Fitzsimons MF (2012) Removal of atrazine from river waters by indigenous microorganisms. Environmental Chemistry Letters 10: 89-96

Tappin AD, Loughnane JP, McCarthy AJ, Fitzsimons MF (2014) Bacterio-plankton transformation of diazepam and 2-amino-5-chlorobenzophenone in river waters. Environmental Science-Processes \& Impacts 16: 2227-2236

Tijani JO, Fatoba OO, Babajide OO, Petrik LF (2016) Pharmaceuticals, endocrine disruptors, personal care products, nanomaterials and perfluorinated pollutants: a review. Environmental Chemistry Letters 14: 27-49

Uchida H, Suzuki T, Takeuchi H, Arenovich T, Mamo DC (2011) Low dose vs standard dose of antipsychotics for relapse prevention in schizophrenia: meta-analysis. Schizophrenia Bulletin 37: 788-799

Villeneuve DL, Garcia-Reyero N, Martinovic D, Mueller ND, Cavallin JE, Durhan EJ, Makynen EA, Jensen KM, Kahl MD, Blake LS, Perkins EJ, Ankley GT (2010a) I. Effects of a dopamine receptor antagonist on fathead minnow, Pimephales promelas, reproduction. Ecotoxicology and Environmental Safety 73: 472-477

Villeneuve DL, Garcia-Reyero N, Martinovic D, Mueller ND, Cavallin JE, Durhan EJ, Makynen EA, Jensen KM, Kahl MD, Blake LS, Perkins EJ, Ankley GT (2010b) II: Effects of a dopamine receptor antagonist on fathead minnow dominance behavior and ovarian gene expression in the fathead minnow and zebrafish. Ecotoxicology and Environmental Safety 73: 478-485

von der Ohe PC, Dulio V, Slobodnick J, de Deckere E, Kuhne R, Ebert RU, Ginebreda A, de Cooman W, Schuurmann G, W B (2011) A new risk assessment approach for the prioritization of 500 classical and emerging organic contaminants as potential river basin specific pollutants under the European Water Framework Directive. Science of the Total Environment 409: 2064-2077

Warhurst DC, Steele JCP, Adaga IS, Craig JC, Cullander C (2003) Hydroxychloroquine is much less active than chloroquine against chloroquine-resistant Plasmodium falciparum, in agreement with its physicochemical properties. Journal of Antimicrobial Chemotherapy 52: 188-193

West CE, Rowland SJ (2012) Aqueous phototransformation of diazepam and related human metabolites under simulated sunlight. Environmental Science \& Technology 46: 47494756

WHO (2015) Model list of essential medicines, 19th edn.http://www.who.int/medicines/publications/essentialmedicines/en/. Accessed $18 \mathrm{Jul}$ 2016 
Wicker J, Lorsbach T, Gütlein M, Schmid E, Latino D, Kramer S, Fenner K (2016) enviPath - The environmental contaminant biotransformation pathway resource. Nucleic Acids Research 44: D502-D508

Yamamoto H, Nakamura Y, Moriguchi S, Nakamura Y, Honda Y, Tamura I, Hirata Y, Hayashi A, Sekizawa J (2009) Persistence and partitioning of eight selected pharmaceuticals in the aquatic environment: laboratory photolysis, biodegradation, and sorption experiments. Water Research 43: 351-362

Zurita J, Jos A, del Peso A, Salguero M, López-Artíguez M, repetto G (2005) Ecotoxicological evaluation of the antimalarial drug chloroquine. Aquatic Toxicology 75: 97-107 
Table 1: Structural information on the compounds studied.

\begin{tabular}{|c|c|c|c|}
\hline Compound $^{\mathrm{a}}$ & IUPAC name $^{\mathrm{a}}$ & CAS No. & Structure $^{\mathrm{a}}$ \\
\hline $\begin{array}{c}\text { peptide } \\
\left(\mathrm{C}_{17} \mathrm{H}_{27} \mathrm{O}_{5} \mathrm{~N}_{3}\right)\end{array}$ & Glycyl-L-leucyl-L-tyrosine & $4306-24-5$ & \\
\hline $\begin{array}{c}\text { Chloroquine } \\
\text { diphosphate } \\
\left(\mathrm{C}_{18} \mathrm{H}_{26} \mathrm{ClN}_{3}\right)\end{array}$ & N'-(7-chloroquinolin-4-yl)-N,N-diethyl-pentane-1,4-diamine & $50-63-5$ & \\
\hline $\begin{array}{l}\text { quinine hemisulfate } \\
\text { monohydrate } \\
\left(\mathrm{C}_{20} \mathrm{H}_{24} \mathrm{~N}_{2} \mathrm{O}_{2}\right)^{\mathrm{a}}\end{array}$ & $\begin{array}{l}(R) \text {-(6-methoxyquinolin-4-yl })((2 S, 4 S, 8 R)-8 \text {-vinylquinuclidin- } \\
\text { 2-yl)methanol }\end{array}$ & $303137-00-0$ & \\
\hline $\begin{array}{c}\text { fluphenazine } \\
\text { hydrochloride } \\
\left(\mathrm{C}_{22} \mathrm{H}_{26} \mathrm{~F}_{3} \mathrm{~N}_{3} \mathrm{OS}\right)\end{array}$ & $\begin{array}{l}\text { 2-[4-[3-[2-(trifluoromethyl)-10H-phenothiazin-10- } \\
\text { yl]propyl]-piperazin-1-yl]ethanol }\end{array}$ & $69-23-8$ & \\
\hline $\begin{array}{c}\text { levamisole } \\
\text { hydrochloride } \\
\left(\mathrm{C}_{11} \mathrm{H}_{12} \mathrm{~N}_{2} \mathrm{~S}\right)^{\mathrm{a}}\end{array}$ & (6S)-6-phenyl-2,3,5,6-tetrahydroimidazo[2,1-b][1,3]thiazole & $16595-80-5$ & \\
\hline
\end{tabular}

${ }^{\mathrm{a}}$ Main molecule only. 
Table 2: Acid dissociation constant $\left(\mathrm{pK}_{\mathrm{a}}\right)^{\mathrm{a}}$, octanol-water solubility co-efficient $\left(\log \mathrm{K}_{\mathrm{ow}}\right)^{\mathrm{a}}$ and octanol-water distribution co-efficient $\left(\log \mathrm{D}_{\text {ow }}\right)$ data for chloroquine, quinine, levamisole and fluphenazine. Calculated extent of pharmaceutical ionisation is also shown.

\begin{tabular}{cccccc}
\hline & $\mathrm{pK}_{\mathrm{a} 1}$ & $\mathrm{pK}_{\mathrm{a} 2}$ & $\log \mathrm{K}_{\mathrm{ow}}$ & $\begin{array}{c}\text { \% Ionised } \\
\left(\mathrm{at} \mathrm{pH} 7.4^{\mathrm{c}}\right)\end{array}$ & $\begin{array}{c}\log \mathrm{D}_{\mathrm{ow}}{ }^{\mathrm{d}} \\
\left(\text { at } \mathrm{pH} 7.4^{\mathrm{c}}\right)\end{array}$ \\
\hline Chloroquine & $9.94-10.87$ & $7.44-8.50$ & $3.93-5.28$ & $>99$ & $-0.67-2.42$ \\
Quinine & $8.4-9.05$ & $4.13-4.32$ & $2.51-3.44$ & $91-98$ & $0.85-2.40$ \\
Levamisole & 6.98 & & $1.84-2.36$ & 28 & $1.70-2.22$ \\
Fluphenazine & $7.84-8.21$ & 3.98 & $3.97-4.4$ & $72-86$ & $3.10-3.83$ \\
\hline
\end{tabular}

a These data include both measured and predicted values, and were obtained from www.drugbank.ca and references/links given within

${ }^{\mathrm{b}}$ Calculated from: $\frac{1}{1+10^{-1\left(p H-p K_{a 1}\right)}}$ (ECETOC, 2013)

${ }^{c}$ Environment Agency of England, unpublished data

${ }^{\mathrm{d}}$ Calculated from equations 2 and 3 in the text 
(a) Concentration $\left(\mu \mathrm{mol} \mathrm{L}{ }^{-1}\right)$

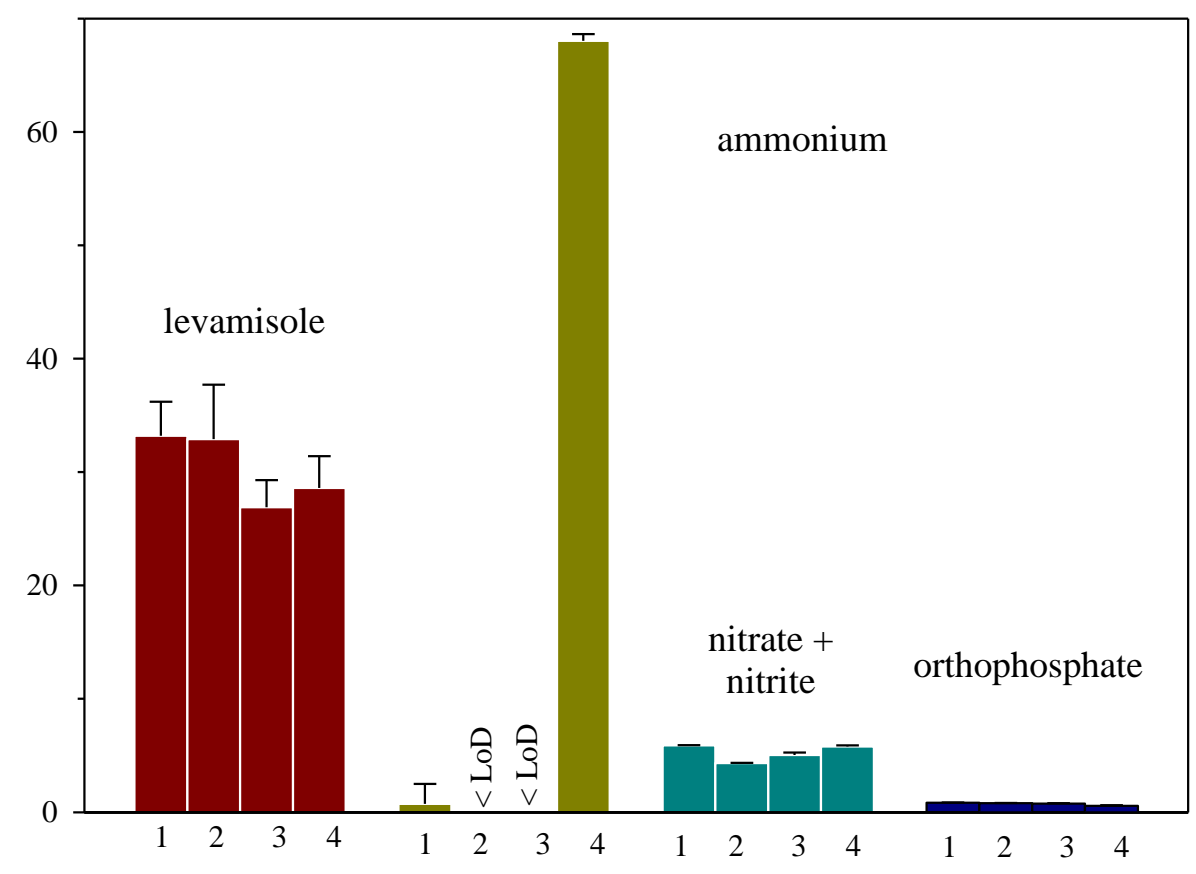

(b) Relative intensity (\%)

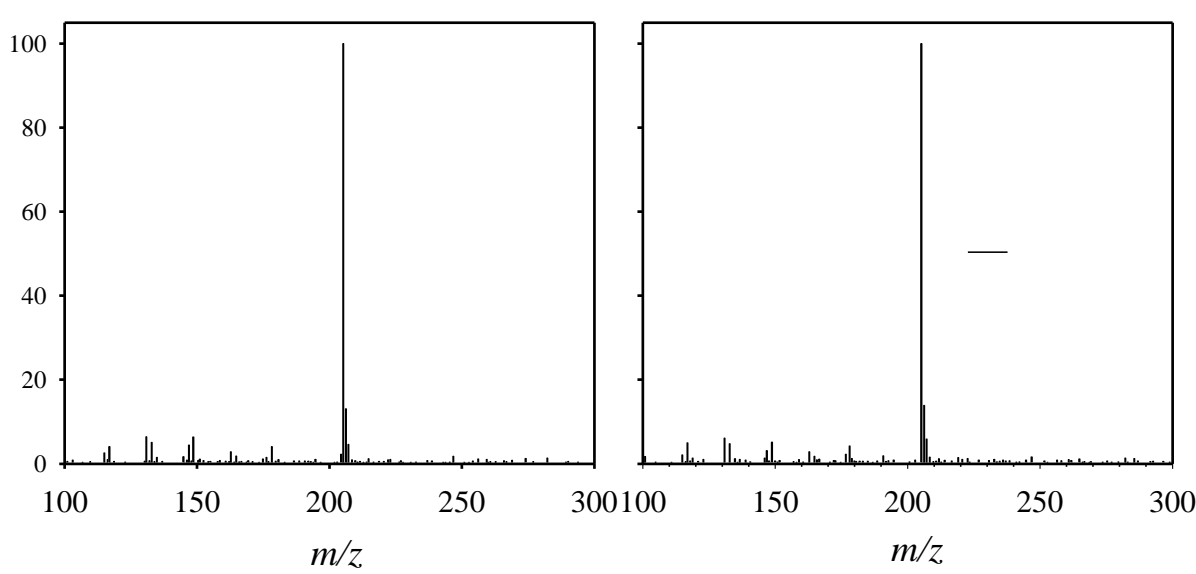

Figure 1: (a) Concentrations of levamisole, ammonium, nitrate+nitrite and orthophosphate in each microcosm at days 0 and $21.1, \mathrm{t}=$ day $0 ; 2, \mathrm{t}=$ day 21 abiotic control; $3, \mathrm{t}=$ day 21 bacterio-plankton + levamisole; $4, \mathrm{t}=$ day 21 bacterio-plankton + levamisole + labile organic matter. Error bars represent $\pm 1 \sigma$ of the results from duplicate incubations with each sample analysed 3-5 times $(n=6-10)$. $<\mathrm{LoD}$, lower than limit of detection. Concentrations of levamisole were reduced by 19 and $13 \%$ in incubations 3 and 4, respectively. (b) Ion chromatograms (relative abundance of ion $(\%)$ vs. $\mathrm{m} / \mathrm{z}$ ) of levamisole in solution in a standard (left panel) and at day 21 (right panel). The horizontal bar shows the range in $\mathrm{m} / \mathrm{z}$ values of possible transformation products predicted by the EAWAG Biocatalysis and Biodegradation Database. 


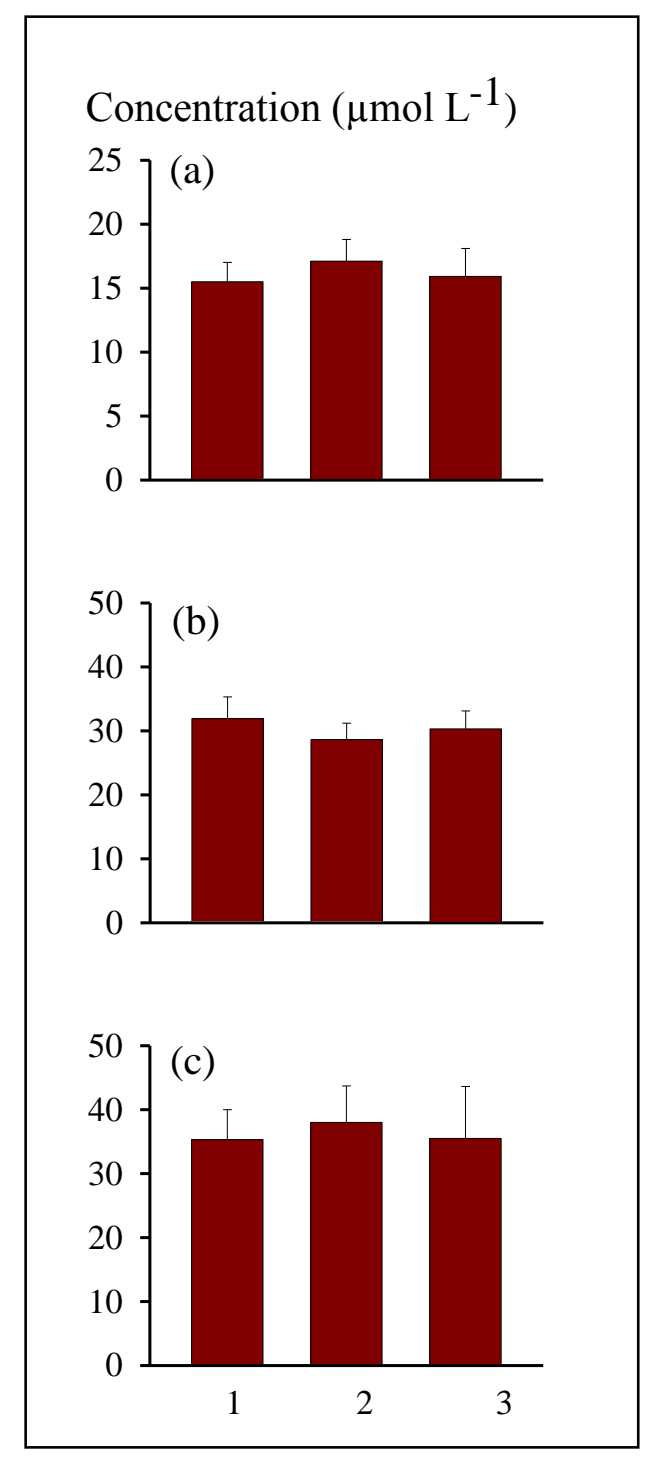

Figure 2: Concentrations of (a) fluphenazine, (b) quinine and (c) chloroquine in each microcosm at days 0 and $21.1, \mathrm{t}=$ day $0 ; 2, \mathrm{t}=$ day 21 abiotic control; $3, \mathrm{t}=$ day 21 bacterioplankton plus pharmaceutical. Error bars represent $\pm 1 \sigma$ of the results from duplicate incubations with each sample analysed five times $(n=10)$. Concentrations of the pharmaceuticals were not significantly different after 21 days under the different incubation conditions. 